\title{
POLA HUBUNGAN PATRON- KLIEN PADA KOMUNITAS NELAYAN DI KELURAHAN MALABRO KECAMATAN TELUK SEGARA KOTA BENGKULU
}

\section{The Pattern of Patron- Client Relationship in Fishermen Community in Malabro Municipal, Teluk Segara District, Bengkulu City}

\author{
Herman Sinaga, Septri Widiono, dan Irnad \\ Jurusan Sosial Ekonomi Pertanian Fakultas Pertanian \\ Universitas Bengkulu
}

\begin{abstract}
This research aimed to describe the characteristic of fishing activities in Malabro Municipal, Teluk Segara District, Bengkulu city and to describe the pattern of patronclient relationship between wholesaler, vessel owner and fishermen. This researh conducted using qualitative method. Data collected using obsevation, interview, and documantes information related to this research. Thi result shows that fishermen are using three fishing tools, such as gillnets, payang and trammel nets. These fishing tools will be influence many things like type of vessel, amount of fishermen, and production sharing system. In patron-client relations between wholesaler and boat owner. Wholesaler has a role as patron and the boat owner has a role as client. Patron-client relation is mutual benefit. While, relation between wholesaler or vessel owner and fishermen hasn't shown patron- client relationship but only shown relation of fishing activities.
\end{abstract}

Keywords: Fishing gears, Patron-Client

\section{PENDAHULUAN}

Pantai adalah wilayah di tepi perairan yang dipengaruhi oleh air pasang tertinggi dan air surut terendah. Sedangkan wilayah pesisir adalah wilayah darat di tepi laut yang masih mendapat pangaruh laut seperti pasang surut, angin laut dan perembesan air laut. Dan penduduk yang mendiami wilayah pesisir pada umumnya adalah mereka yang memiliki mata pencaharian sebagai nelayan. Berkaitan dengan wilayah pesisir di atas, Provinsi Bengkulu merupakan provinsi yang memiliki daerah pesisir yang berbatasan langsung dengan Samudera Indonesia dengan garis pantai sepanjang lebih kurang 525 kilometer (BPS, 2010). Salah satu wilayah pesisir di Provinsi Bengkulu adalah Kota Bengkulu yang sekaligus sebagai ibu kota provinsi. Kota Bengkulu sebagai 
salah satu daerah pesisir yang penduduknya bermata pencaharian sebagai nelayan tersebar di beberapa kecamatan.

Jika menyinggung masalah kemiskinan, tidak dapat dipisahkan bahwa salah satu mata pencaharian yang identik dengan kemiskinan adalah nelayan. Menurut Kepala Kelautan dan Perikanan Provinsi Bengkulu, Rinaldi (2014) mengatakan bahwa setengah dari jumlah total nelayan yang ada di Provinsi Bengkulu merupakan nelayan yang tergolong miskin. Nelayan yang tergolong miskin tersebut, yakni nelayan yang mencari ikan di pinggir pantai dengan peralatan tangkap ikan sederhana dan tersebar di sepanjang pesisir Provinsi Bengkulu.

Salah satu strategi adaptasi dalam mengatasi kesulitan ekonomi yang dihadapi oleh nelayan adalah menjalin hubungan sosial. Hubungan yang dimaksud adalah hubungan yang membentuk hubungan patron-klien. Menurut Scott seperti dikutip oleh Kusnadi (2000), hubungan patron-klien merupakan kasus khusus hubungan antara dua orang yang sebagian besar melibatkan persahabatan instrumental, di mana seseorang yang kedudukan sosialnya lebih tinggi (patron) menggunakan pengaruh sumber daya yang dimilikinya untuk memberikan perlindungan atau keuntungan, atau kedua-duanya kepada orang yang memiliki status sosial yang lebih rendah (klien). Selanjutnya klien membalas pemberian tersebut dengan memberikan dukungan dan bantuan termasuk jasa-jasa pribadi kepada patron. Menurut Legg yang dikutip oleh Kusnadi (2000), tujuan dari kedua belah pihak baik patron maupun klien menjalin hubungan patron-klien ini adalah memperoleh keuntungan berupa barang, jasa atau sumber daya lain yang tidak dapat diperoleh melalui cara lain atas pengorbanan yang telah meraka berikan. Menurut Hefni (2009), hubungan patron-klien ditandai dengan patron memberikan pekerjaan, perlindungan, infrastruktur dan berbagai manfaat lainnya kepada klien yang tidak berdaya dengan imbalan klien memberikan berbagai bentuk kesetiaan, pelayanan dan bahkan dukungan politik kepada patron. Dengan menjalin hubungan patronklien diharapkan mampu mengatasi tekanan ekonomi nelayan.

Secara keseluruhan keberadaan nelayan tradisional berada pada garis kemiskinan dan secara khusus nelayan tradisional di Provinsi Bengkulu Kelurahan Malabro Kecamatan Teluk Segara. Strategi adaptasi yang dilakukan oleh nelayan di daerah tersebut dalam mengatasi kesulitan ekonomi dalam kehidupan sehari-hari adalah menjalin hubungan patron-klien dengan juragan. Menurut Rindawati (2012), masyarakat nelayan yang tinggal di Kelurahan Malabro merupakan masyarakat yang homogenitas baik secara mata pencaharian maupun agama serta memiliki ikatan kekeluargaan yang tinggi sesama masyarakat nelayan. Hal ini memungkinkan dapat digunakan sebagai strategi adaptasi untuk mengatasi kemiskinan yakni menjalin hubungan secara vertikal yang berbentuk hubungan patron-klien. 
Berdasarkan pemaparan di atas maka penelitian ini bertujuan (1) untuk mendeskripsikan karakteristik kegiatan melaut pada komunitas nelayan di Kelurahan Malabro Kecamatan Teluk Segara Kota Bengkulu dan (2) untuk mendeskripsikan pola hubungan patron-klien pada komunitas nelayan di Kelurahan Malabro Kecamatan Teluk Segara Kota Bengkulu.

\section{METODOLOGI}

Penelitian ini dilakukan di Kelurahan Malabro Kecamatan Teluk Segara Kota Bengkulu. Lokasi penelitian ini dilakukan secara sengaja (purposive) dengan alasan bahwa daerah ini merupakan salah satu daerah yang penduduknya mayoritas nelayan. Untuk mendapatkan data di lapangan, peneliti menggunakan 3 informan meliputi 1 juragan dan 2 nelayan pemilik kapal dan 4 responden meliputi 2 nelayan pemilik kapal dan 2 ABK. Jenis data yang digunakan adalah data primer dan data sekunder. Data primer diperoleh melalui pengamatan di lapangan dan wawancara dan data sekunder diperoleh melalui kajian dokumentasi. Penelitian ini menggunakan analisis kualitatif model Miles dan Huberman. Miles dan Huberman (1992) menyatakan bahwa analisis data kualitatif memiliki 3 tahapan yaitu reduksi data (Data Reduction), penyajian data (Data Display), dan menarik kesimpulan (Verification). Untuk menguji keabsahan data perlu dilakukan uji kredibilitas. Penelitian ini menggunakan triangulasi sumber, yaitu pengecekan kembali data yang diperoleh melalui wawancara kembali kepada sumber yang berbeda dalam waktu yang berbeda (Ahmadi, 2014).

\section{HASIL DAN PEMBAHASAN}

\section{Karakteristik Melaut Nelayan}

\section{Alat Tangkap dan Perahw/Kapal}

Nelayan di Kelurahan Malabro menggunakan 3 jenis alat tangkap yaitu jaring insang, pukat payang dan pukat irik. Penggunaan alat tangkap ini akan mempengaruhi beberapa aspek dalam melakukan penangkapan meliputi jenis kapal yang digunakan, jumlah ABK, jenis ikan hasil tangkapan, kekuatan alat tangkap dan waktu melaut. Secara rinci perbedaan alat tangkap yang digunakan dapat di lihat pada Tabel 1.

Berdasarkan hasil pengamatan di lapangan dan wawancara, kapal yang terdapat di Kelurahan Malabro ada 2 jenis yaitu kapal motor dan kapal motor tempel. Jenis kapal tersebut disesuaikan dengan kebutuhan melaut nelayan dan jenis alat tangkap yang digunakan. 
Tabel 1. Perbedaan Alat Tangkap Jaring, Pukat Payang dan Pukat Irik di Kelurahan Malabro

\begin{tabular}{llccc}
\hline \multirow{2}{*}{ No } & \multirow{2}{*}{ Keterangan } & \multicolumn{3}{c}{ Jenis Alat Tangkap } \\
\cline { 3 - 5 } & \multirow{2}{*}{ Jenis Kapal } & Jaring Insang & Pukat Payang & Pukat Irik \\
\hline 2. & Jumlah ABK (orang) & $2-3$ & Perahu motor & $\begin{array}{c}\text { Kapal motor } \\
\text { tempel }\end{array}$ \\
3. & Waktu Melaut (WIB) & $03.00-11.00$ & $00.00-10.00$ & $02.00-08.00$ \\
4. & Ikan Jenis Tangkapan & Sarden, Kerapu & Tembolo, & \\
& & $\begin{array}{l}\text { Kembung, } \\
\text { Kakap, Tenggiri, }\end{array}$ & $\begin{array}{c}\text { Kembung, } \\
\text { Tongkol, Hiu }\end{array}$ & Udang dan Teri \\
5. & Kapasitas Kapal & 3 ton & 3 ton & $200 \mathrm{~kg}$ \\
\hline
\end{tabular}

Sumber: Data Primer Diolah, 2015

\section{Wilayah Tangkap}

Batas wilayah tangkap atau zona tangkap di Kelurahan Malabro tidak berdasarkan asal daerah nelayan tersebut melainkan berdasarkan kategori nelayan. Kategori nelayan yang dimaksud adalah nelayan modern dan nelayan tradisional. Nelayan yang dikategorikan sebagai nelayan modern adalah nelayan yang menggunakan jenis kapal dengan kapasitas lebih dari 5 ton. Sedangkan yang dikatergorikan nelayan tradisional adalah nelayan yang menggunakan jenis kapal yang cenderung berukuran kecil yaitu berkapasitas di bawah 5 ton. Nelayan modern tidak diperbolehkan melakukan aktivitas penangkapan ikan di wilayah perairan yang berjarak kurang dari 5 mil dari garis pantai. Artinya, wilayah perairan yang berjarak 5 mil dari garis merupakan wilayah penangkapan nelayan tradisional.

Peraturan mengenai batas wilayah tangkap antara nelayan modern dengan nelayan tradisional didasari oleh kesepakatan semua nelayan yang berada di wilayah pesisir Bengkulu. Tujuan ditetapkan peraturan ini adalah untuk menjaga keberadaan nelayan tradisional agar tetap mampu melakukan kegiatan melaut.

\section{Perekrutan ABK}

Dalam perekrutan ABK menjadi tanggung jawab seorang kapten kapal. ABK yang telah direkrut merupakan rekrutan yang bersifat tidak permanen dan tanpa perjanjian secara tertulis. Artinya ABK dapat berpindah ke kapal lain sewaktu-waktu. Pada umumnya di Kelurahan Malabro biasanya seorang ABK itu sendiri yang akan menjumpai kapten kapal untuk melakukan perjanjian keikutsertaan dalam melaut. Seorang kapten kapal akan "dicari" oleh ABK berdasarkan pengalaman melautnya. Semakin berpengalaman seorang kapten 
kapal maka semakin banyak pula ABK yang ingin ikut serta dalam melaut. Hal ini dipengaruhi oleh asumsi seorang ABK yaitu jika seorang kapten kapal memiliki pengalaman melaut yang lebih maka kapten kapal tersebut lebih mengetahui wilayah-wilayah laut yang berpontesi menghasilkan tangkapan yang banyak. Dengan demikian akan mempengaruhi besaran upah yang akan diterimanya nanti.

\section{Karakteristik Hubungan Patron-Klien}

Salah satu strategi adaptasi yang dilakukan nelayan dalam mengatasi permasalah ekonomi yang dihadapinya adalah menjalain hubungan sosial. Hubungan yang dimaksud adalah hubungan yang bersifat patron-klien. Hubungan tersebut akan mempengaruhi 2 aspek, yakni hubungan yang bersifat ekonomi dan hubungan yang bersifat non-ekonomi. Hubungan yang bersifat ekonomi merupakan aspek yang menerima dampak dari hubungan yang terjalin meliputi mata pencaharian. Hubungan yang bersifat non-ekonomi adalah aspek yang menerima dampak dari hubungan yang terjalin di luar aspek ekonomi seperti hubungan sosial, budaya, politik dan jaminan sosial.

Berkaitan dengan hal di atas, hubungan patron-klien yang terjadi di daerah tersebut antara juragan dengan nelayan pemilik kapal. Yang dimaksud juragan dalam penelitian ini adalah pihak yang memasarkan hasil tangkapan dan memiliki status sosial yang lebih tinggi dari nelayan karena memiliki kekuasaan akan pasar yang lebih besar yakni memiliki jaringan pemasaran dibandingkan dengan nelayan, sedangkan yang dimaksud dengan nelayan pemilik kapal adalah pihak yang memilik kapal yang ikut serta melaut maupun yang tidak ikut melaut. Hubungan patron-klien tersebut terjadi disebabkan beberapa faktor, yaitu (1) jaringan pemasaran yang tidak dimiliki oleh nelayan pemilik kapal sehingga membuat mereka merasa tergantung kepada juragan dalam memasarkan hasil tangkapan dan (2) mata pencaharian sebagai nelayan sangat tergantung pada musin ikan dan alam meyebabkan meraka tidak memiliki pendapatan pasti sehingga dirasakan perlu sebuah jaminan untuk memenuhi kebutuhan hidup (konsumsi, kesehatan, dan pendidikan) ketika mengalami krisis ekonomi. Hubungan antara juragan atau nelayan pemilik kapal dengan ABK tidak menunjukkan adanya hubungan patron-klien. Hal ini disebabkan oleh ABK yang direkrut dapat berpindah kapal sewaktu-waktu (tidak permanen) sehingga juragan atau nelayan pemilik kapal merasa enggan memberikan sebuah perlindungan (jaminan) di luar kegiatan melaut.

\section{Pola Hubungan Patron-Klien yang Bersifat Ekonomi}

\section{Sistem Pemasaran}

Pemasaran hasil tangkapan merupakan bagian dari rangkaian dari kegiatan usaha melaut. Pemasaran ini sangat mempengaruhi pendapatan yang 
akan diterima oleh pihak-pihak yang terkait dalam proses penangkapan meliputi juragan, pemilik kapal, kapten kapal, ABK dan anak sampan. Transaksi pemasaran hasil tangkapan di Kelurahan Malabro terjadi di darat secara tatap muka (langsung) antara juragan dengan nelayan dalam menyerahkan hasil tangkapan untuk dipasarkan maupun juragan dengan pedagang pengecer dalam melakukan transaksi jual-beli. Juragan biasanya menjual hasil tangkapan kepada pedagang pengecer yang berasal dari dalam maupun luar Kota Bengkulu. Sistem pemasaran yang diterapkan oleh juragan ada 2 yaitu sistem timbang dan sistem lelang. Pada kedua sistem ini, harga ditetapkan berdasarkan kesepakatan antara juragan dan pedagang pengecer. Penetapan harga biasanya dipengaruhi oleh harga pasar dan tingkat kesegaran ikan. Harga yang disepakati oleh juragan dan pedagan pengecer biasanya dibawah harga pasar.

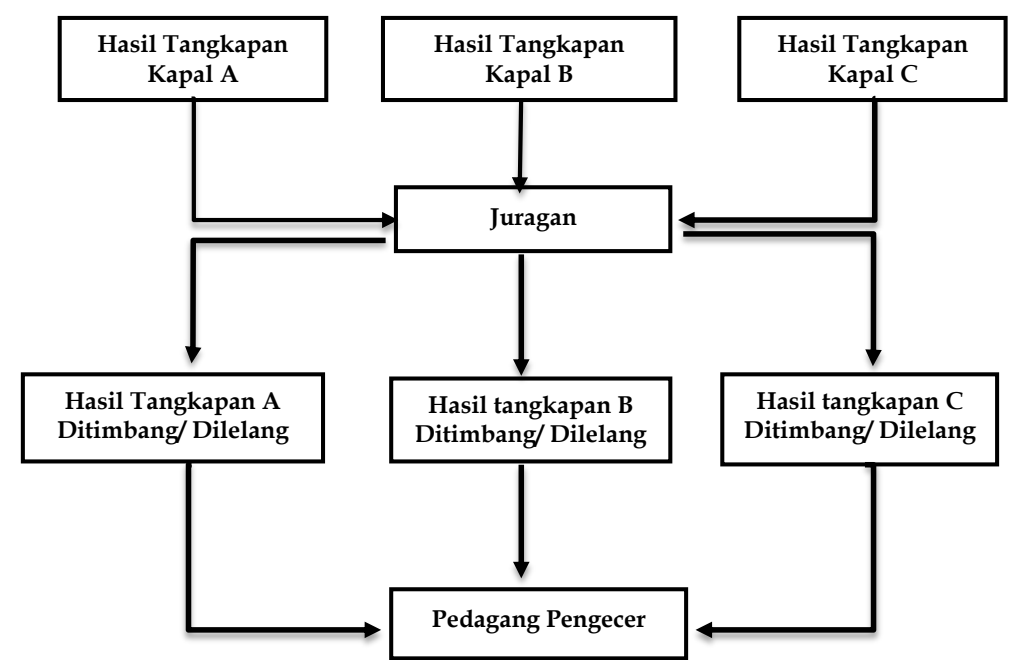

Gambar 1. Pemasaran dengan Sistem Timbang

Sumber: Data Primer Diolah, 2015

Pemasaran dengan sistem timbang biasanya diterapkan pada alat tangkap jaring insang dan pukat payang. Pada pemasaran dengan sistem ini, hasil tangkapan diserahkan nelayan pemilik kapal kepada juragan. Kemudian juragan akan menjualnya dengan cara ditimbang kepada pedangan pengecer sesuai dengan kemampuan pedagang pengecer tersebut untuk membelinya. Dalam proses pemasaran ini, juragan akan mencatat seluruh timbangan yang sudah dijual kepada pedangan pengecer sebagai bukti kepada nelayan pemilik kapal. Dari hasil catatan tersebut bertujuan untuk mengetahui jumlah hasil tangkapan dan memperkecil kesalahan saat melakukan bagi hasil. Hal ini perlu dilakukan karena satu orang juragan biasanya akan memasarkan hasil tangkapan dari 2-3 kapal. Sedangkan pemasaran dengan sistem lelang sedikit berbeda dengan pemasaran dengan sistem timbang. Pada sistem lelang, hasil 
tangkapan tidak lagi ditimbang ketika menjual kepada pedagang pengecer melainkan dilelang. Lelang dalam hal ini diartikan harga ikan hasil tangkapan merupakan hasil negosiasi antara juragan dengan pedagang pengecer. Dalam sistem ini sangat diperlukan keahlian khusus dalam menafsirkan jumlah hasil tangkapan oleh juragan maupun pedagang pengecer sehingga tidak menimbulkan kerugian yang besar setelah proses transaksi. Pemasaran dengan sistem ini biasanya diterapakan pada alat tangkap pukat irik.

Dalam melakukan pemasaran dapat terjadi tindakan kecurangan yang dilakukan oleh juragan. Kecurangan tersebut berupa memanipulasi hasil timbangan dalam melaporkan catatan penjualan kepada nelayan pemilik kapal. Hal ini dapat memicu keretakan hubungan yang antara juragan dengan nelayan pemilik kapal. Dan jika hal tersebut terjadi, tak jarang pula nelayan pemilik kapal memilih untuk pindah juragan.

\section{Sistem Bagi Hasil}

Dalam pola hubungan sistem bagi hasil dalam hubungan produksi penangkapan ikan oleh nelayan di Kelurahan Malabro, nelayan pemilik kapal tidak menentukan target minimal yang harus dipenuhi oleh awak kapal. Pada komunitas nelayan di Kelurahan Malabro, sistem bagi hasil dikenal berdasarkan pada alat tangkap. Hasil yang dibagikan merupakan pendapatan setelah total penerimaan dikurangi dengan total biaya operasial melaut kecuali biaya bekal. Biaya operasional yang dimaksud meliputi biaya BBM, oli kapal, dan alat pendukung alat tangkap seperti rumpun pohan pinang pada alat tangkap pukat payang. Biaya operasial tersebut dikembalikan kepada juragan atau nelayan pemilik kapal sesuai dengan biaya yang awal yang dikeluarkan sebelum melaut. Untuk perbekalan makanan oleh pihak yang melaut ditanggung masing-masing individu. Sistem bagi hasil berdasarkan yang diterapkan oleh nelayan tidak memiliki perjanjian tertulis melainkan sudah menjadi sebuah tradisi dari nenek moyang meraka.

Dalam sistem bagi hasil yang diterapkan oleh nelayan menggunakan alat tangkap jaring insang adalah 5\% untuk juragan, 25\% untuk nelayan pemilik kapal, 2,5\% untuk anak sampan dan 67,5\% dibagi antara kapten kapal dan ABK. Sistem bagi hasil yang diterapkan dalam penggunaan alat tangkap pukat payang cenderung sama dengan sistem bagi hasil dengan alat tangkap jaring. Hal yang membedakan adalah hasil yang diterima oleh juragan lebih besar yaitu sebesar $10 \%$ sedangkan untuk nelayan pemilik kapal dan anak sampan sama yaitu $25 \%$ dan 2,5\% dan 62,5\% dibagi antara kapten kapal dan ABK. Sistem bagi hasil dari kedua alat tangkap ini kapten kapal akan mendapatkan 3 kali upah yang diperoleh oleh seorang ABK. Dalam sistem bagi hasil dengan alat tangkap pukat irik cenderung berbeda dengan sistem bagi hasil dengan alat tangkap pukat payang maupun jaring. Dalam sistem bagi hasil ini yang mendapat bagian adalah juragan, nelayan pemilik kapal, dan ABK sedangkan anak sampan tidak 
mendapat bagian dalam bagi hasil. Hal ini dikarenakan dalam pukat irik menggunakan perahu motor tempel yang kecil yakni perahu dengan kapasitas 200 kilogram sehingga tidak memerlukan jasa anak sampan saat kapal tidak melaut untuk menjaga kapal. Dalam penggunaan alat tangkap pukat irik, jumlah ABK adalah 1 orang sedangkan kapten kapal merupakan pemilik kapal itu sendiri. Dalam sistem bagi hasil dengan alat tangkap pukat irik, juragan mendapat bagian 5\%, pemilik kapal 70\% dan ABK 25\%.

\section{Bantuan dan Perlindungan Saat Melaut}

Peranan seorang juragan sebagai parton tidak hanya diperlukan dalam memasarkan hasil tangkapan namun juga sangat penting dalam memberi bantuan dan perlindungan saat nelayan melaut. Bantuan yang diperlukan nelayan yang dimaksud memberikan pertolongan ketika kapal sedang rusak di tengah laut. Bantuan tersebut seperti meminta bantuan kepada nelayan lain yang sedang berada di darat untuk menjemput kapal yang rusak tersebut di tengah laut. Kapal mengalami kerusakan di tengah laut biasanya dapat diketahui jika kapal belum kembali ke darat setalah beberapa jam dari waktu normalnya kembali ke darat. Untuk biaya dalam melakukan penjemputan kapal yang tersebut biasanya ditanggung oleh juragan jika biayanya belum terlalu besar dan jika biaya terbilang cukup besar biasanya ditanggung oleh juragan dan nelayan pemilik kapal. Bentuk perlindungan juragan terhadap nelayan terlihat ketika terjadi konflik dengan nelayan lain saat melaut seperti nelayan modern melanggar batas wilayah tangkap nelayan tradisional. Selain pelanggaran wilayah tangkap oleh nelayan modern, kerusakan alat tangkap nelayan akibat terkena kapal nelayan lain sering dijumpai ketika melaut. Dan jika hal ini terjadi, maka seorang juragan berperan memberi perlindungan dan menyelasaikan masalah tersebut. Berdasarkan hasil wawancara kepada informan, jika kejadian tersebut terjadi biasanya alternatif penyelesaiannya adalah memperbaiki alat tangkap yang rusak apabila alat tangkap tersebut masih memungkinkan untuk diperbaiki atau mengganti alat tangkap yang rusak jika alat tersebut sudah rusak parah dan tidak dapat diperbaiki lagi. Untuk biaya perbaikan ataupun ganti rugi alat tangkap yang rusak sepenuhnya ditanggung oleh nelayan yang melakukan kerusakan tersebut. untuk menyelesaikan masalah tersebut dilakukan secara musyawarah sesama juragan bukan sesama nelayan pemilik kapal.

Peranan juragan juga sangat diperlukan oleh nelayan pemilik kapal berupa bantuan materi ketika nelayan pemilik kapal mengalami krisis ekonomi. Ketika nelayan pemilik kapal mengalami kekuragan modal untuk melaut maka nelayan akan meminjam uang kepada juragan. Uang tersebut dipinjam untuk digunakan sebagai biaya operasional melaut seperti biaya bahan bakar (BBM), oli kapal bahkan biaya perawatan kapal dan alat tangkap. 


\section{Pola Hubungan Patron-Klien yang Bersifat Non-Ekonomi}

Peranan juragan sebagai patron pada komunitas nelayan di Kelurahan Malabro tidak hanya dirasakan penting di dalam kegiatan melaut. Pengaruh patron juga dapat dirasakan penting di luar kegiatan melaut yaitu mendapat jaminan sosial seperti patron memberi bantuan jika salah satu anggota keluarga klien sedang sakit atau mengalami musibah. Namun, tidak semua klien mendapatkan jaminan sosial dari patron dalam hubungan patron-klien. Sebagai bentuk membalas kebaikan yang diberikan oleh patron, klien akan memberikan dukungan termasuk dengan jasa pribadi klien. Pada komunitas nelayan di Kelurahan Malabro, kebaikan patron dibalas dalam bentuk kesetiaan (loyalitas). Kesetiaan klien yang dimaksud terlihat ketika nelayan tidak berpindah-pindah juragan dalam melakukan pemasaran hasil tangkapan. Hal ini dilakukan oleh klien dikarenakan sudah merasa hutang budi kepada patron. Kesetiaan nelayan terhadap patron menjadi salah satu faktor kelanggengan hubungan yang mereka jalin. Walaupun dengan demikian, kesetiaan yang diberikan kepada patron bukan semata-mata kerena adanya rasa berhutang budi tetapi juga karena adanya ketergantungan. Menurut Herfni (2009), ketidakmampuan klien membalas kebaikan patron akan memunculkan rasa hutang budi kepada patron, yang selanjutnya dapat melahirkan ketergantungan.

\section{SIMPULAN DAN SARAN}

\section{Simpulan}

Jenis alat tangkap yang digunakan oleh nelayan di Kelurahan Malabro terdapat 3 jenis, yaitu jaring insang, pukat payang dan pukat irik. Setiap alat tangkap tersebut memiliki karakteristik yang berbeda dalam melaut. Jenis alat tangkap yang digunakan oleh nelayan sangat mempengaruhi beberapa aspek dalam melakukan penangkapan meliputi jenis perahu yang digunakan, jumlah $A B K$, jenis hasil tangkapan, waktu melaut dan sistem bagi hasil yang diterapkan.

Dalam hubungan patron-klien terjadi antara juragan dengan nelayan pemilik kapal untuk semua jenis alat tangkap. Juragan berperan sebagai patron karena memiliki kekuatan, kekayaan dan pengaruh terhadap nelayan pemilik kapal sedangkan nelayan pemilik kapal berperan sebagai klien karena menerima pengaruhi dari patron. Hubungan patron-klien ini bersifat saling menguntungkan dan cenderung bertahan dalam jangka waktu panjang dikarenakan kekuatan posisi patron yang menyebabkan posisi klien menjadi terikat. Sementara hubungan antara juragan maupun nelayan pemilik kapal dengan ABK tidak menunjukkan adanya hubungan patron-klien tetapi hanya sebatas hubungan kerja. 


\section{Saran}

Dalam kegiatan melaut, wilayah tangkap menjadi salah satu faktor yang perlu diperhatikan karena mempengaruhi tingkat keberhasilah usaha melaut. Di samping itu, wilayah tangkap dapat juga mempengaruhi interaksi antara nelayan di laut sehingga disarankan pemerintah lebih meningkatkan pengawasan batas-batas wilayah tangkap di laut untuk menghindari konflik antara nelayan tradisional dan nelayan modern.

Sementara itu, kegiatan melaut pada komunitas nelayan di Kelurahan Malabro membentuk suatu pola hubangan patron-klien yang terjadi antara juragan dengan nelayan pemilik kapal untuk semua jenis alat tangkap dan dapat dikatakan sebagai salah satu strategi nelayan dalam mengatasi kesulitan ekonomi. Untuk menghindari retaknya hubungan tersebut yang terjalin antara juragan dan nelayan pemiliki kapal, sebaiknya juragan selaku patron tetap menjaga kepercayaan dari klien dengan cara tidak melakukan kecuragan dalam menjual hasil tangkapan. Dengan demikian hubungan patron-klien tetap terjalin dalam jangka waktu panjang dikarenakan hubungan tersebut memberikan keuntungan kepada kedua belah pihak.

\section{DAFTAR PUSTAKA}

Ahmadi, R. 2014. Metodologi Penelitian Kualitatif. Yogyakarta: Ar-Ruzz Media.

BPS. 2010. Provinsi Bengkulu dalam Angka 2010. Bengkulu. Katalog BPS :1102001.17.

Hefni, M. 2009. Patron-Klien Relationship pada Masyarakat Madura. Karsa. April 2009. 15(1): 15-24.

Kusnadi. 2000. Nelayan: Strategi Adaptasi dan Jaringn Sosial. Bandung: Humaniora Utama Press Bandung.

Miles, Matthew dan Michael Huberman. 1992. Analisis Data Kualitatif. Jakarta : Penerbit Universitas Indonesia.

Rinaldi. 2014. 5.000 Nelayan di Bengkulu Dikategorikan Miskin. http://sp.beritasatu.com. (diakses: 6 Februari2015)

Rindawati, S. 2012. Strategi Peningkatan Masyarakat Nelayan di Kota Bengkulu. Jurnal Ekonomi dan Informasi Akutansi (Jenius). Sept 2012. 2(3). 291-314. 